\title{
Uji Antagonisme Lentinus cladopus LC4 terhadap Ganoderma boninense Penyebab Penyakit Busuk Pangkal Batang Kelapa Sawit
}

\author{
Erni Angraini ${ }^{1}$ \\ ${ }^{1}$ FKIP Pendidikan Biologi, Universitas Muhammadiyah Palembang \\ Email: erniangraini.81@gmail.com
}

\begin{abstract}
The growth of oil palm can not be separated from disease attack. One of the diseases that attack is the Base Stem Rot disease caused by Ganoderma boninense. Efforts to control the pest and disease one of them by using Lentinus Cladopus LC4 biological controller so that the purpose of this study is to determine the potential of L.cladopus LC4 as biological controlling agent $G$. boninense. The method used is L. cladopus LC4 antagonism test against $G$. boninense. The results showed that $L$. cladopus LC4 had antagonistic potency against $G$. boninense pathogen, although the mechanism did not show any inhibition zone. Therefore, L.cladopus LC4 may be considered for the prevention and control of plant diseases in the field.
\end{abstract}

Keywords: Lentinus cladopus LC4, Ganoderma boninense, antagonism test.

\begin{abstract}
Abstrak
Pertumbuhan kelapa sawit tidak terlepas dari serangan penyakit. Salah satu penyakit yang menyerang adalah penyakit Busuk Pangkal Batang (BPB) yang disebabkan oleh Ganoderma boninense. Upaya pengendalian terhadap hama dan penyakit tersebut salah satunya dengan menggunakan pengendali hayati Lentinus cladopus LC4 sehingga tujuan penelitian ini yaitu untuk mengetahui potensi L. cladopus LC4 sebagai agens hayati pengendali G. boninense. Metode yang digunakan yaitu dengan uji antagonisme L. cladopus LC4 terhadap G. boninense. Hasil penelitian membuktikan bahwa L. cladopus LC4 memiliki potensi antagonistik terhadap cendawan patogen G. boninense, walaupun mekanisme yang terjadi tidak menunjukkan adanya zona hambat. Oleh karena itu, L. cladopus LC4 dapat dipertimbangkan untuk pencegahan dan pengendalian penyakit tanaman di lapangan.
\end{abstract}

Kata kunci : Lentinus cladopus LC4, Ganoderma boninense, uji antagonisme

\section{Pendahuluan}

Pertumbuhan kelapa sawit tidak terlepas dari serangan penyakit. Salah satu penyakit yang menyerang adalah penyakit Busuk Pangkal Batang (BPB) (Semangun, 2000). Saat ini penyakit BPB merupakan penyakit yang penting, terutama pada kebun-kebun kelapa sawit yang telah mengalami peremajaan. Semakin sering suatu kebun mengalami peremajaan maka semakin tinggi persentase kejadian penyakit BPB. Hal ini terjadi karena setelah cendawan menginfeksi tanaman, areal pertanaman akan terus terkontaminasi dan inokulum patogen akan terakumulasi sejalan dengan semakin seringnya penanaman kelapa sawit (Susanto, et al., 2005).

Penyebab penyakit BPB adalah Ganoderma boninense yang merupakan cendawan patogen tular tanah. Patogen ini tidak hanya menyerang tanaman tua, tetapi juga yang masih muda. Saat ini, laju infeksi penyakit BPB berjalan semakin cepat, terutama pada tanah dengan tekstur berpasir (Susanto, et al., 2013). Penyakit ini juga menyebabkan kehilangan hasil secara luas pada perkebunan kelapa sawit. Penyakit ini telah menyebabkan kematian kelapa sawit di beberapa perkebunan Indonesia hingga
$80 \%$ atau lebih dari populasi kelapa sawit dan hal tersebut menyebabkan penurunan produk kelapa sawit per satuan luas (Susanto, 2002).

Pada saat ini upaya pengendalian terhadap hama dan penyakit tanaman masih mengandalkan penggunaan pestisida sebagai upaya pengendalian utama. Kenyataannya menunjukkan bahwa upaya pengendalian dengan menggunakan senyawa kimia bukan merupakan alternatif yang terbaik, karena sifat racun yang terdapat dalam senyawa tersebut dapat meracuni manusia, ternak piaraan, serangga penyerbuk, musuh alami, tanaman, serta lingkungan yang dapat menimbulkan polusi bahkan pemakaian dosis yang tidak tepat bisa membuat hama dan penyakit menjadi resisten. Selain itu dengan adanya aplikasi pestisida sintetik yang tidak bijaksana dapat memicu timbulnya patogen yang resisten terhadap pestisida sintetik yang digunakan, sehingga perlu adanya alternatif lain dalam pencegahan penyakit BPB yang disebabkan oleh Ganoderma boninense yaitu dengan pengendalian hayati.

Salah satu metode pengendalian hayati adalah dengan menggunakan mikroorganisme. Lentinus merupakan spesies yang ternyata berpotensi menghasilkan berbagai macam 
metabolit yang dapat dimanfaatkan untuk kepentingan kesehatan dan industri. Sudirman (2005) mengemukakan bahwa Lentinus cladopus LC4 memiliki potensi lebih dalam menekan pertumbuhan mikroorganisme dibandingkan isolat Lentinus tropis lainnya. L. cladopus LC4 menghasilkan setidaknya delapan senyawa antimikroba (ACs) yang aktif melawan patogen tanaman (Xanthomonas campestris pv. glycines). (Sudirman, 2010). Penelitian terdahulu mengenai Pengendalian hayati pada $G$. boninense dilakukan dengan pemanfaatan agens biologi antagonis seperti cendawan Trichoderma sp. SBJ8 (Alviodinasyari, et al., 2005) dan endomikoriza (Simanjuntak, et al., 2013). Ekstrak miselium L. cladopus LC4 dapat menghambat beberapa patogen tanaman seperti Rhizoctonia solani, Rigidiporus lignosus, Phytophthora capsici, Pseudomonas syringae (Mulyaningsih, 2002).

Berdasarkan permasalahan di atas, maka perlu dilakukannya penelitian untuk mengetahui potensi L. cladopus LC4 sebagai agens hayati pengendali $G$. boninense sehingga membuka peluang pemanfaatan $L$. cladopus LC4 sebagai agen pengendalian hayati bagi patogen $G$. boninense di lapangan.

\section{Metode}

Bahan-bahan yang digunakan di dalam penelitian ini adalah jamur L. cladopus LC4 dan G. boninense isolat GKSA yang merupakan hasil isolasi dan koleksi Prof. Dr. Lisdar I. Sudirman. Penelitian ini menggunakan media Potato Dextrose Agar (PDA) untuk peremajaan dan uji antagonisme isolat jamur, pembibitan pada media jagung, dan budidaya jamur dengan menggunakan serbuk gergaji kayu, dedak padi, $1,5 \%$ gipsum dan $1,5 \%$ kapur $\left(\mathrm{CaCO}_{3}\right)$, dan air.

\section{Peremajaan isolat L. cladopus LC4.}

Isolat L. cladopus LC4 diremajakan pada media Malt Extract Agar (MEA) di dalam cawan petri (diameter $9 \mathrm{~cm}$ ), kemudian diinkubasi pada suhu $35{ }^{\circ} \mathrm{C}$ selama \pm 7 hari.

\section{Peremajaan isolat G.boninense}

Cendawan G.boninense

GKSA ditumbuhkan selama 7 hari dalam suhu kamar pada media PDA. Peremajaan dilakukan sampai 10 hari sebelum digunakan untuk uji antagonisme.

\section{Pengujian antagonisme $L$. cladopus LC4 terhadap G. boninense}

Uji antagonisme antara isolat L.-cladopus LC4 dengan $G$. boninense GKSA dengan metode kultur ganda yang telah dimodifikasi (Mbarga, et al., 2012). Pengujian antagonisme dengan menggunakan biakan ganda (dual culture) yaitu dilakukan dengan menumbuhkan L. cladopus LC4 dan $G$. boninense GKSA pada cawan Petri yang berisi media PDA secara berhadapan dengan jarak $2 \mathrm{~cm}$ dari garis tengah cawan Petri dengan masing masing isolat berdiameter $0,6 \mathrm{~cm}$. Pada kultur tunggal, masing-masing kontrol diinokulasi pada hari yang sama, sedangkan pada kultur ganda isolat LC4 terlebih dahulu diinokulasi kemudian setelah 7 hari isolat G.boninense diinokulasikan. Peubah yang diamati adalah presentase penghambatan cendawan patogen oleh cendawan antagonis dan lebar zona hambatan, seperti rumus dibawah ini :

$$
\begin{aligned}
& \text { \% H LC4 }=\frac{\text { Kontrol LC4 }- \text { Perlakuan LC4 }}{\text { Kontrol LC4 }} \\
& \% \text { H GKSA }=\frac{\text { Kontrol GKSA }- \text { Perlakuan GKSA }}{\text { Kontrol GKSA }} \\
& \text { \% H Interaksi LC4 }- \text { GKSA }=\frac{\text { Perlakuan LC4 }- \text { Perlakuan GKSA }}{\text { Perlakuan LC4 }}
\end{aligned}
$$

Adapun cara meletakkan Inokulum $L$. cladopus LC4 dan G. Boninense GKSA (Gambar 1) adalah sebagai berikut :
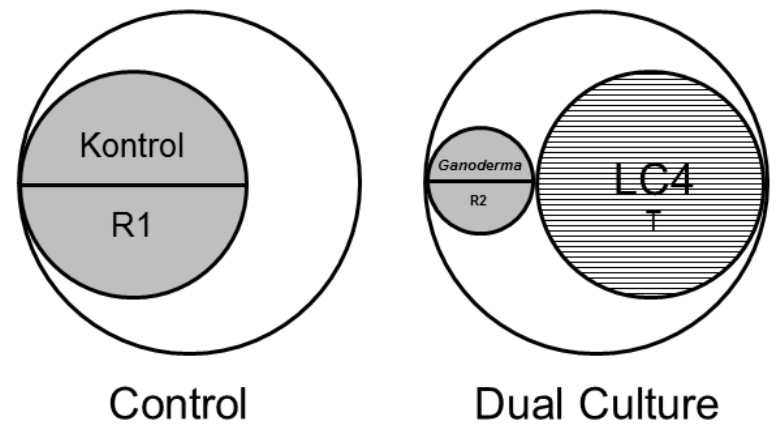

Gambar 1. Kontrol dan Uji Antagonis L. cladopus LC4 dan G. Boninense GKSA

\section{Pengamatan mikroskopik interaksi $L$. cladopus LC4 dengan G.boninense}

Pertemuan kedua isolat di dalam cawan dipotong dengan menggunakan jarum ose, kemudian dengan bantuan selotip ditempelkan ke gelas objek.

\section{Pembuatan preparat awetan}

Gliserol $85 \% \quad(42,5 \quad \mathrm{~mL})$ ditambahkan aquades $50 \mathrm{~mL}$ kemudian direndam di dalam cawan petri 15-30 menit. Setelah itu, sampel diangkat dan dikeringkan.

\section{Pembuatan Bibit Jamur}

Bibit jamur masing-masing isolat dibuat dengan menggunakan pipilan jagung. Pipilan jagung kemudian dimasukkan ke dalam botol dan disterilisasi menggunakan autoklaf (suhu $121^{\circ} \mathrm{C}$, tekanan $1 \mathrm{~atm}$ ) selama 20 menit. Pipilan jagung yang telah steril diinokulasikan dengan isolat masing-masing jamur dan diinkubasi pada suhu ruang hingga seluruh media dipenuhi miselium jamur.

\section{Budidaya Jamur}

Isolat L. cladopus CL4 dan G. boninense dibudidayakan pada substrat yang terdiri dari serbuk gergajian kayu. Pada substrat 
ditambahkan $15 \%$ dedak padi, 1,5\% gipsum dan $1,5 \%$ kapur $\left(\mathrm{CaCO}_{3}\right)$, kemudian diberi air hingga kadar airnya mencapai 70-75\%. Selanjutnya, substrat dimasukkan ke dalam kantong plastik berukuran $1 \mathrm{~kg}$ dan disterilisasi menggunakan autoklaf (suhu $121{ }^{\circ} \mathrm{C}$, tekanan $1 \mathrm{~atm}$ ). Masingmasing isolat ditanam pada kantong plastik tahan panas. Kantong plastik berisi substrat yang telah steril didinginkan pada suhu ruang dan masingmasing diinokulasi dengan bibit jamur L. cladopus LC4 dan $G$. boninense sebanyak 2 sendok teh perkantong secara aseptik. Kantong plastik berisi bibit jamur diinkubasi di rumah jamur selama 30 hari pada suhu $28-30{ }^{\circ} \mathrm{C}$ dan diamati pertumbuhan L. cladopus LC4 dan G. Boninense.

\section{Hasil dan Pembahasan}

Hasil penelitian menunjukkan bahwa pada kontrol, kedua isolat telah tumbuh pada hari pertama setelah diinkubasi. Pertumbuhan isolat L.cladopus LC4 lebih cepat dibanding isolat G.boninense (Gambar 2 dan Gambar 3). Pada hari ke-11 inkubasi, jari-jari isolat $G$. boninense mencapai 3,8 cm, sedangkan jari-jari LC4 sebesar $6,5 \mathrm{~cm}$ (Gambar 2). Isolat $G$. boninense diinokulasikan pada hari ke-9 pada uji antagonisme.

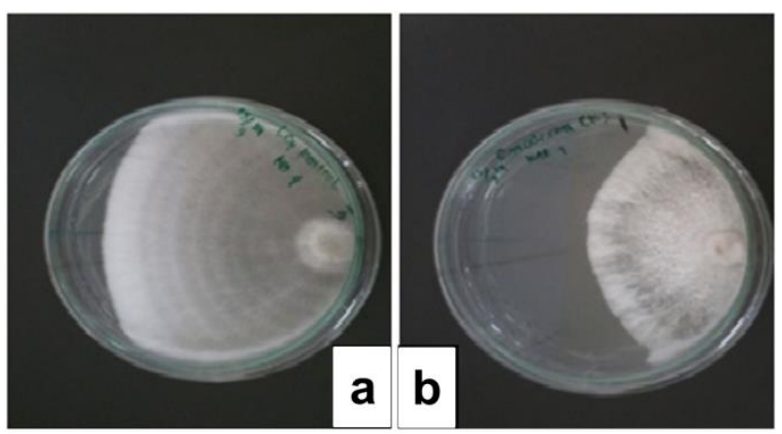

Gambar 2. (a) isolat LC4 hari ke-11 (b) isolat GKSA hari ke-11

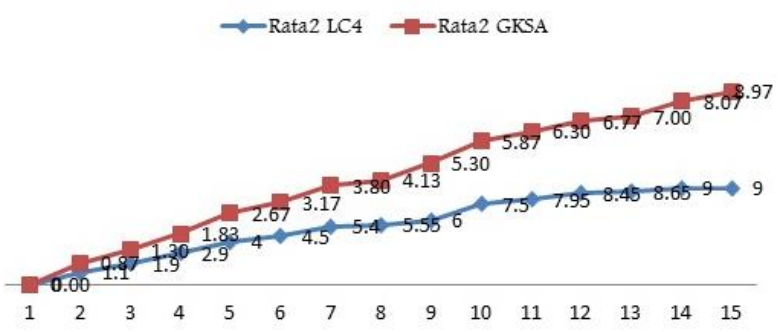

Gambar 3. Rata-rata pertumbuhan kontrol LC4 dan GKSA

Uji antagonisme menunjukkan potensi $L$. cladopus LC4 sebagai agen pengendalian hayati bagi G.boninense. Hal tersebut karena keberadaan isolat LC4 mampu menghambat pertumbuhan isolat $G$. boninense (Gambar 4). Pertumbuhan L. cladopus LC4 dan G. boninense terlihat adanya perkembangan, setelah pengamatan hari ke-9, namun yang lebih cepat menunjukan perkembangan adalah LC4, dimana jari-jari $L$. cladopus LC4 setelah hari ke-10 berukuran 4,75 cm dibandingkan $G$. boninense berukuran 0,43 cm (Gambar 6). Banyak agen pengendalian hayati yang dapat menghambat pertumbuhan $G$. boninensis antara lain: isolat Trichoderma sp. SBJ8 dapat menghambat pertumbuhan $G$. boninense pada hari ke-4 sebesar 65,25\% (Alviodinasyari, et al., 2005). Simanjuntak et al. (2013), menyatakan bahwa aplikasi mikoriza mampu mengendalikan penyakit busuk pangkal batang kelapa sawit yang disebabkan oleh $G$. boninense pada pembibitan kelapa sawit MN sampai tujuh bulan setelah aplikasi Ganoderma.

Antagonisme L. cladopus LC4 dengan G. boninense GKSA tidak mengakibatkan terbentuknya zona bening yang terdapat di antara koloni kedua isolat (Gambar 4), tetapi Berdasarkan pengamatan mikroskopik, terlihat bahwa ada hifa yang terpilin pada saat terjadinya interaksi (Gambar 5). Hal ini bisa menjadi alasan pemanfaatan LC4 sebagai antagonis dari $G$. boninensis GKSA. Antagonisme L. cladopus LC4 dengan GKSA tidak mengakibatkan terbentuknya zona penghambatan. Hal ini bukan berarti LC4 tidak menghasilkan metabolit spesifik ekstraseluler, karena pada beberapa penelitian dilaporkan bahwa ekspresi antibiosis pada antagonisme in vitro dipengaruhi oleh media yang digunakan. Achmad et al. (2011), mempelajari antagonisme pada media padat yang melibatkan $T$. harzianum, zona penghambatan terbentuk baik pada PDA maupun MEA, akan tetapi zona penghambatan pada antagonisme yang melibatkan T. pseudokoningii terbentuk hanya pada MEA, sedangkan pada PDA tidak. Seperti yang kita ketahui bahwa LC4 tumbuh baik pada media MEA sedangkan pada penelitian ini menggunakan media PDA.

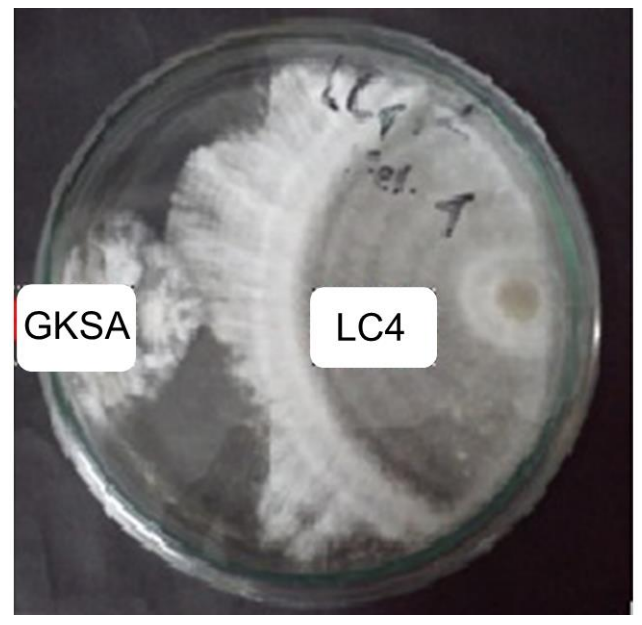

Gambar 4. Antagonisme Lentinus cladopus LC4 terhadap Ganoderma boninensis 


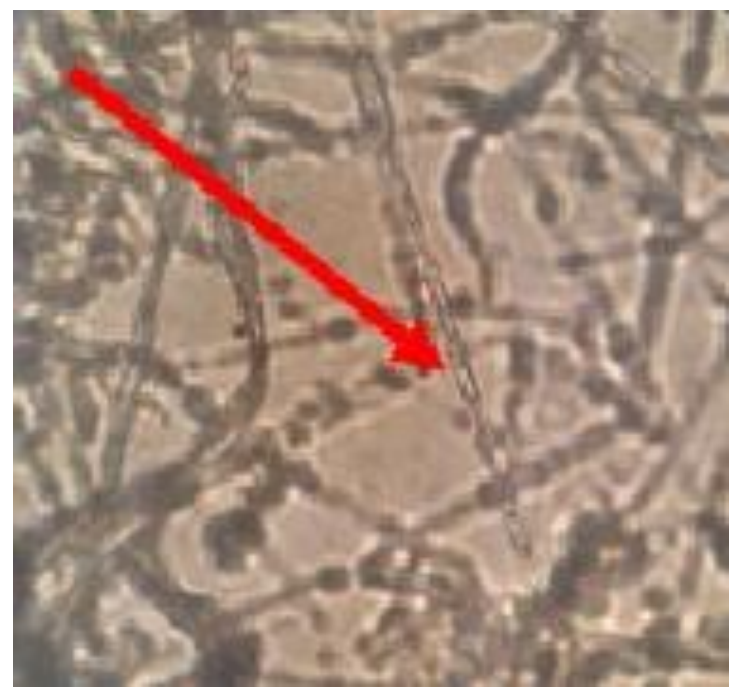

Gambar 5. Interaksi isolat GKSA dengan LC4 (perbesaran 100x)

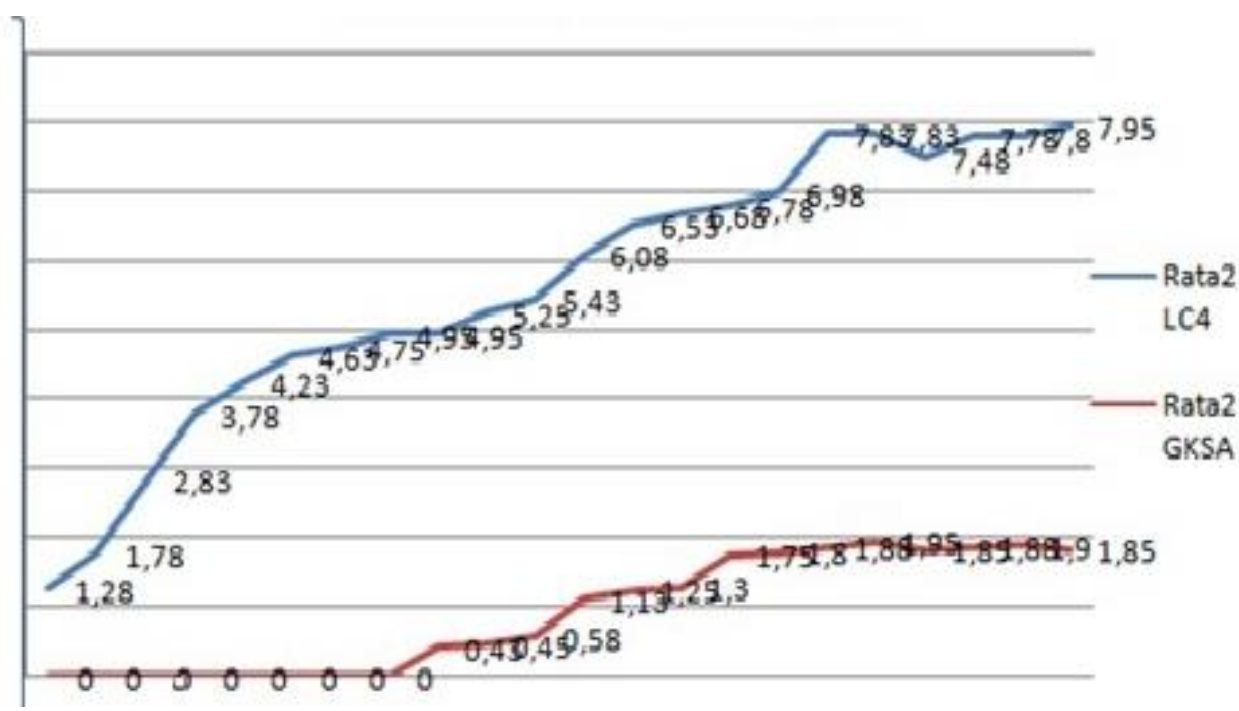

Gambar 6. Uji Antagonisme Pertumbuhan LC4 dan Ganoderma boninense dari hari ke hari

Tabel 1. Persentase nilai hambat interaksi LC4GKSA

\begin{tabular}{cc}
\hline Cawan petri & $\begin{array}{c}\text { Nilai hambat interaksi LC4- } \\
\text { GKSA }\end{array}$ \\
\hline 1 & $75,67 \%$ \\
2 & $68,75 \%$ \\
3 & $81,25 \%$ \\
4 & $75,90 \%$ \\
\hline
\end{tabular}

Berdasarkan Tabel 1. dapat diketahui bahwa LC4 mampu menghambat pertumbuhan Ganoderma sebesar $75,67 \%$, 68,75\%, $81,25 \%$, dan $75,90 \%$. Hal ini, tidak sejalan dengan pengamatan interaksi yang diinokulasikan pada baglog. Pada baglog terlihat miselium LC4 menghitam dan tidak mampu memenuhi baglog, sedangkan GKSA juga tidak mampu untuk memenuhi baglog padahal pada kontrolnya miselia memenuhi baglog (Gambar 7). Interaksi yang terjadi pada baglog tidak dapat menunjukkan potensi isolat LC4 sebagai antagonis GKSA, karena hampir keseluruhan baglog terkontaminasi oleh Trichoderma dan cendawan lain. Hasil yang sama juga dilaporkan oleh Aprilisma (2017), menyatakan bahwa pertumbuhan isolat GKSA juga dihambat oleh cendawan kontaminan Trichoderma sp. yang diisolasi dari media tanam yang hanya mengandung formulasi Bio-LC4 tidak steril sedangkan pada semua perlakuan yang mengandung media tanam tidak steril, pertumbuhan isolat GKSA dihambat oleh beberapa cendawan kontaminan, antara lain: genus $X$, dan genus $Y$. Trichoderma spp. mempunyai kecepatan pertumbuhan koloni paling cepat, hanya membutuhkan waktu 7-9 hari dibandingkan pertumbuhan $G$. boninense yang membutuhkan waktu 15-40 hari pada medium PDA. (Aeny, 2010). Pertumbuhan G. boninense penyebab penyakit busuk pangkal batang kelapa sawit juga dapat dihambat oleh Trichoderma harzianum (Izzati \& Abdullah, 2008). 
Pada baglog terlihat bahwa LC4 memiliki hifa yang lama kelamaan menghitam. Hal ini mungkin merupakan sebuah cara survive yang dilakukan LC4 dari senyawa metabolit yang dihasilkan oleh GKSA. Pertumbuhan GKSA pun tidak ada yang memenuhi baglog, karena adanya penghambatan oleh LC4. Isolat Trichoderma viride, $T$. harzianum, $T$. koningii dapat menghambat pertumbuhan jamur Ganoderma boninense secara in vitro, tetapi pengaruh antar isolat Trichoderma tidak berbeda satu sama lain (Aeny, 2010). Hasil pengujian pada perlakuan media tanam yang mengandung formulasi Bio-
LC4 steril atau yang mengandung media tanam steril baik tanpa suplemen maupun dengan suplemen isolat GKSA mampu tumbuh dengan kisaran $82-83 \%$, sedangkan formulasi Bio-LC4 sebagai media tanam $G$. boninense isolat GKSA di cawan petri menunjukkan bahwa isolat GKSA tumbuh dengan kisaran 2.6-18.4\% pada semua perlakuan media tanam yang mengandung formulasi Bio-LC4 tidak steril ataupun yang mengandung media tanam tidak steril baik tanpa suplemen maupun dengan suplemen. Aktivitas formulasi Bio-LC4 hilang setelah disterilisasi (Aprilisma, 2017).

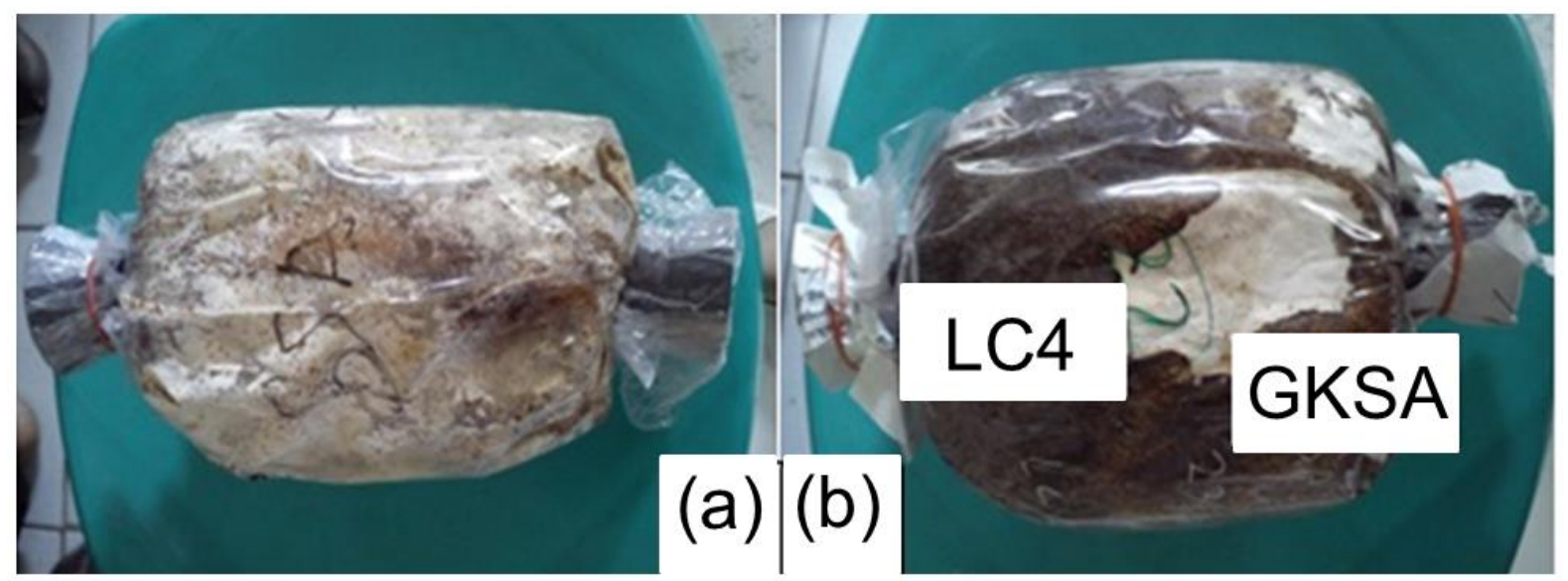

Gambar 7. Interaksi pada baglog (a) kontrol GKSA (b) Antagonisme LC4-GKSA

\section{Simpulan}

Penelitian ini membuktikan bahwa Lentinus cladopus LC4 memiliki potensi antagonistik terhadap cendawan patogen Ganoderma boninense, walaupun mekanisme yang terjadi tidak menunjukkan adanya zona hambat. Oleh karena itu, Lentinus cladopus LC4 dapat

\section{Daftar Referensi}

Achmad \& Yulisman, D., 2011. Potensi dua isolat lokal Pleurotus sp. sebagai antagonis terhadap Ganoderma sp. Jurnal Penelitian Tanaman Industri, 17(4), pp. 174-178.

Aeny, T. N., 2010. Pengaruh beberapa iolat Trichoderma spp. pada pertumbuhan in vitro Ganoderma boninense, penyebab busuk pangkal batang kelapa sawit (Elaeis Guineensis). Lampung, Universitas Lampung.

Alviodinasyari, R., Martina, A. \& Lestari, W., 2005. Pengendalian Ganoderma boninense oleh Trichoderma sp. SBJ8 pada kecambah dan bibit kelapa sawit (Elaeis guineensis Jacq.). JOM FMIPA, 2(1), pp. 99-107. dipertimbangkan untuk pencegahan dan pengendalian penyakit tanaman di lapangan.

\section{Ucapan Terima Kasih}

Peneliti mengucapkan terimakasih kepada tim laboratorium Mikrobiologi dan Mikrotropisian IPB 2015.

Aprilisma, G., 2017. Pengaruh Formulasi BIO-LC4 Terhadap Pertumbuhan Ganoderma Boninense, Bogor: Institut Pertanian Bogor.

Izzati, M. Z. N. A. \& Abdullah, F., 2008. Disease Suppression in Ganoderma-infected oil palm seedlings treated with Trichoderma harzianum. Plant Protect. Sci, 44(3), pp. 101-107.

Mbarga, J. B., Hoopen, G. M. T., Kuaté, J., Adiobo, A., Ngonkeu, M. E. L., Ambang, z., Akoa, A., Tondje, P. R. \& Begoude, B. A. D., 2012. Trichoderma asperellum: A potential biocontrol agent for Pythium myriotylum, causal agent of cocoyam (Xanthosoma sagittifolium) root rot disease in Cameroon. Crop Protection, Volume 36, pp. 18-22.

Mulyaningsih, C., 2002. Aktivitas ekstrak miselium Lentinus cladopus isolat LC terhadap 
beberapa mikrob patogen tanaman dan cendawan penghasil alfatoksin, Bogor: Institut Pertanian Bogor.

Semangun, H., 2000. Penyakit-Penyakit Tanaman Perkebunan di Indonesia. Yogyakarta: Gajah Mada University Press.

Simanjuntak, D., F. \& Susanto, A., 2013. Efikasi Mikoriza dan Trichoderma sebagai pengendali penyakit busuk pangkal batang (Ganoderma) dan sebagai pemacu pertumbuhan di pembibitan kelapa sawit. Widyariset, 16(2), p. 233-242.

Sudirman, L. I., 2005. Deteksi senyawa antimikrob yang diisolasi dari beberapa Lentinus tropis dengan metode bioautografi. Hayati, 12(2), pp. 67-72.

Sudirman, L. I., 2010. Partial purification of antimicrobial compounds isolated from mycelia of tropical Lentinus cladopus LC4. HAYATI Journal of Biosciences, 17(2), pp. 63-67.

Susanto, A., 2002. Kajian pengendalian hayati Ganoderma boninense Pat. penyebab penyakit busuk pangkal batang kelapa sawit, Bogor: Institut Pertanian Bogor.

Susanto, A., Sudharto, P. S. \& Purba, R. Y., 2005. Enhancing biological control of basal stem rot disease (Ganoderma boninense) in oil palm plantations. Mycopathologia, Volume 159, p. 153-157.

Susanto, A., Prasetyo, A. E., Priwiratama, H., Wening, S. \& Surianto., 2013. Ganoderma boninense penyebab penyakit busuk batang atas kelapa sawit. I Fitopatol Indones, 9(4), p. 123-126. 